\title{
Memoire of a momentous intellectual journey
}

\begin{tabular}{|c|c|}
\hline $\begin{array}{l}\text { Book Title: } \\
\text { Living betwee } \\
\text { Belief: The Mc }\end{array}$ & $\begin{array}{l}\text { Science and } \\
\text { dern Dilemma }\end{array}$ \\
\hline Book Cover: & \\
\hline $\begin{array}{l}\text { Living } \\
\text { between } \\
\begin{array}{r}\text { Sciel } \\
\text { and B }\end{array}\end{array}$ & ef \\
\hline $\begin{array}{l}\text { Author: } \\
\text { Charles Villa-V }\end{array}$ & icencio \\
\hline $\begin{array}{l}\text { ISBN: } \\
\text { elSBN: } 97819\end{array}$ & 28314851 \\
\hline $\begin{array}{l}\text { Publisher: } \\
\text { African Sun M } \\
\text { *Book price a }\end{array}$ & $\begin{array}{l}\text { edia, } 2021 \\
\text { time of review }\end{array}$ \\
\hline $\begin{array}{l}\text { Review Title: } \\
\text { Memoire of a } \\
\text { intellectual jo }\end{array}$ & $\begin{array}{l}\text { momentous } \\
\text { arney }\end{array}$ \\
\hline $\begin{array}{l}\text { Reviewer: } \\
\text { P.P. (Paul) Kru }\end{array}$ & $\operatorname{ser}^{1}$ \\
\hline $\begin{array}{l}\text { Affiliation: } \\
\text { 'Department } \\
\text { Dogmatology, } \\
\text { Theology, Nor } \\
\text { University, Po } \\
\text { South Africa }\end{array}$ & $\begin{array}{l}\text { Faculty of } \\
\text { th-West } \\
\text { chefstroom, }\end{array}$ \\
\hline $\begin{array}{l}\text { Correspondin } \\
\text { Paul Kruger, } \\
\text { ppkruger@ab }\end{array}$ & $\begin{array}{l}\text { g author: } \\
\text { samail.co.za }\end{array}$ \\
\hline $\begin{array}{l}\text { How to cite th } \\
\text { Kruger, P.P., } 2 C \\
\text { of a momento } \\
\text { journey', In di } \\
56(1), \text { a2814. } \\
\text { org/10.4102/i }\end{array}$ & $\begin{array}{l}\text { is book review: } \\
\text { 22, 'Memoire } \\
\text { us intellectual } \\
\text { Skriflig } \\
\text { https://doi. } \\
\text { ds.v56i1.2814 }\end{array}$ \\
\hline Read online: & \\
\hline 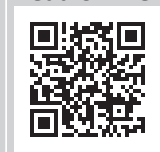 & $\begin{array}{l}\text { Scan this QR } \\
\text { code with your } \\
\text { smart phone or } \\
\text { mobile device } \\
\text { to read online. }\end{array}$ \\
\hline
\end{tabular}

In less than 160 pages, the esteemed author condenses his 'memoire of an intellectual journey, within which the mystery of transcendence and immanence continues to prevail in the face of natural disasters, human evil, and critical thought' (p. xi). This intellectual journey, with the insights it brought about, is shared in such a well-informed, engaged and - nota bene - fair, nuanced and respectful way that it fills one with admiration. His pilgrimage includes a very active and courageous part in the church struggle against Apartheid as well as a long professorship at the University of Cape Town and teaching posts elsewhere. Despite - unknown at the time sharing some Cape Town fresh air with him (my secondary schooling in the shades of Table Mountain), we, of course, hail from different theological and ecclesiastical backgrounds; mine, initially Potchefstroom and then, during the immense social upheavals of the 1960's, my stimulating Amsterdam alma mater, the Free University, where an always widening horizon opened out. Yet, different backgrounds or not, I must admit that the author's pilgrimage struck so many chords with me that it would take much more than this review to record everything. Thus, I for one, can really relate - albeit on another level and perhaps in another degree! - to what his friend and fellow 'Church Struggler', John de Gruchy, in a Foreword writes:

[This is about his] journey from faith to skepticism and disillusionment, his liberating engagement with secular humanism, and his slow but profound rediscovery of the mystery of life to which all religious traditions and scientific inquiry point. (p. $x$ )

The catholicity, coupled with an acute contextual awareness, characterising this work, indeed invite a wide variety of inter-religious and intra-Christian responses on a par with this epitome of theology as 'doing truth in love' (Eph 4:15).

Villa-Vicencio addresses the dilemma of so many people who, in our times, live in the 'interregnum' between science and belief (p. 1). Starting from this observation, he gives an analysis packed with information and undergirded by some of the latest and, as far as I can judge, highly authoritative, many-layered scientific, theological and other research results from the humanities. After the Introduction, the publication is organised into six chapters dealing subsequently with the following: the meeting place between believers, atheists and skeptics; the being of God; Judaism: the spirit of prophecy; Christianity: the humanity of God; Islam: Allah - far and near; and Consciousness: Old and new. Succinctly, the author states about his enterprise: 'The elephant in the room is the challenge of modern science which many believers struggle to hold in creative balance' (p. 8). Instead of achieving such a balance, he sees the majority of believers - concentrating on the Abrahamic faiths of Judaism, Christianity and Islam - as a drift 'between soft fundamentalism and non-cognitive belief, holding their past or present religious memories in tension with modern belief' (p. 120). Rather than attempting to overcome this dilemma by tasking 'premodern science with answering contemporary debates on past modern science' (as many fundamentalists - and even numerous 'more open' believers - want to do) the author rightly prefers, with Wentzel van Huyssteen, a 'transversal reasoning' - not between Newtonian or pre-Darwinian science and anxious, rigidly dogmatic, entrenched theology, but between the latest quantum physics or respectable post-Darwinian research and a theology that is kept open to dialogue towards all sides in a new consciousness of the still 'unknown' and the totally 'unknowable' (pp. 25, 122, 135 - 138). In this quest we should embrace theological and religious variety, while enriching each other with the unrelinquishable core truth (p. 29) of what each believes. As to Christians, we need to broaden our - often held - selective memory of the Jesus of the New Testament into a more holistic view of the inexhaustible depths of his person and work. It is rightly observed that Jesus is, in our modernistic selectivity, frequently viewed and experienced 'as little more than an abstract symbol of bourgeois complacency' (p. 81). Thus, science and belief could be unhooked from the horns of the 'modern dilemma' to move into a more correlative, mutually supportive fulfilling of their various tasks, standing in 'common awe' (yet, no awe is 'common'!) before the great mystery 'in whom we live, we move and have our being' (as St. Paul so aptly quotes from a different-believing, Greek poet (Acts 17) - incidentally, also the first biblical passage to

Copyright: (C) 2022. The Authors. Licensee: AOSIS. This work is licensed under the Creative Commons Attribution License. 
which Calvin explicitly refers in his Institutes (1:1)). This might also free both theology and science from a modernistic, Cartesian anxiety about the phenomena of uncertainty and doubt; paradoxically, still persisting within all our 'unique certainties' (pp. 139 -141).

The author prominently brings the rather underexposed question of the 'neuroscientific revolution' into the ambit of the theology-science debate. I profited particularly from this aspect of his presentation (especially pp. 129 - 134). Speaking though of presentation: with all my appreciation for his emphasis on the necessity of a narrative approach and the inculcation of left-brain thinking in theology, I would personally welcome a little more of these accents in his present discourse, which by and large perhaps displays too much of the traditional overtones typical of more 'one-dimensional', mere logical modes of presentation. Even some traces of the dramatic mode of theologising (see Von Balthasar) - that is, bringing quoted authors in some 'dramatic' interchange with each other - might also have been inserted in a treatise like this splendid one. Tolle, lege! And again! 